\title{
Roman Arbitration in the Greek OiKumene in the Third-Second Century BCE: Some Observations
}

\author{
Maciej Piegdoń \\ Jagiellonian University in Kraków
}

\begin{abstract}
Rome's expansion in the Hellenistic world had an impact on the use of various instruments of diplomacy by the Romans, including arbitration, commonly used by and popular among the Greeks. The Romans did not have the desire to become arbitrators of the Greek world, but it was important to them to take advantage of the situation they encountered there and to achieve their goals. The Greeks, who had been used to employing various, more or less sophisticated, diplomatic instruments, saw the Roman Republic, a new player in their world, in the same way as the other large and mighty powers which could be appealed to as arbitrators. Rome did not become an arbitrator in Greek matters of its own will, but due to the fact that the Greek world itself appointed it to this role when it replaced the Hellenistic monarchies. The Romans became involved in solving disputes in the Greek world only when they had to. Despite being offered this role, the Senate had no intention of being an "arbitration court" for the conflicted Greek states. Roman arbitrators acted on the basis of the authority given to them by the Senate (senatus consulta), which first became familiar with the cause of the dispute. Disputes were usually solved by Roman officials (proconsul, governor) or specially delegated legates and decemviri with prepared instructions which gave them the authority to solve the matter on the spot and to enforce the decisions they made. The procedure applied both to the Greek world and to the western part of the Mediterranean Sea, where Rome held power (North Africa, Italy). However, what differentiated the arbitration in Italy and the western part of Rome's dominion from the one in the Greek world was the Republic appointing other Greek states (poleis or leagues) to arbitrate on its behalf. When deciding to arbitrate, the Romans were usually not interested in the history of the dispute, but solved the disagreement or conflict on the basis of the status quo, without going into the details of who had been right previously. This was different from the rules of arbitration in the Greek world, where earlier mediation was taken into consideration. Perhaps this was a result of the difference between the Roman and the Greek worlds in terms of property right. The Roman law of property had an important distinction between legal ownership of a thing (dominium or proprietas), called property right, and the actual possession of a thing (possessio). For the Republic, this approach made it easier to side with their allies participating in a dispute, even if they were wrong. This attitude mainly protected the interests of the allied state, unless it was beneficial to Rome to act against them.
\end{abstract}

Key words: Arbitratio, Roman Republic, Hellenistic world, mediation. 
Resolving disputes between individuals, as well as larger groups of people (tribes, states) by means of arbitration/mediation/adjudication has taken place in the majority of societies, from ancient Egypt and Mesopotamia ${ }^{1}$ to the present day. Almost every community, as well as all legislation systems, have procedures which help solve conflicts amicably with the assistance of a neutral person or institution. The Greek world knew and used such institutions in relations between states. In Rome, arbitration as a means of amicably settling private and public disputes was also known at least from the fourth century BCE.

For this reason, it is worth comparing the Greek and Roman models of arbitration/mediation/adjudication and the methods they were used, as well as noting the genesis of this institution in the two worlds from the earliest times, and showing their mutual influence. Despite some similarities between the two models, the Romans arriving in the Hellenistic world in the late third century BCE had their own political goals to pursue, so they understood the institution somewhat differently than the Greeks, for whom it was one of the many tools for achieving compromise in a politically broken up and conflicted oikumene. Initially, Roman diplomatic practices met with the incomprehension of the Greek states. On the other hand, the Romans were not always well-versed in the complicated arcana of Greek dependencies, relations and disputes, which sometimes went back a very long way. Rome's prolonged presence in this area enabled it to pursue a policy of expansion on the basis of its own practices, but to pragmatically use Greek methods as well.

By becoming involved in the Aegean matters, the Romans became entangled in local disputes between Greek cities. These conflicts had sometimes gone on for hundreds of years (like the ones between cities in Asia Minor, the Aegean Sea, or Crete) and were a matter of primary importance for the involved parties. The Greeks treated the Roman Republic like other large and powerful states (Hellenistic monarchies, leagues) and turned to it as if to a new hegemon. They expected the new dominant power, like those that had come before it, to find a just solution to conflicts.

In the Greek world, arbitration/mediation as a method of solving conflicts between various parties (individuals and communities) appeared very early. The first information on the subject can be found in the works of Homer and Hesiod. ${ }^{2}$ Their descriptions show procedures which are also known from later times. Therefore, this was an institution which took its shape at least in the Archaic period, and its complex methods show that both private and public (institutionalised) arbitration existed as early as the eighth/ seventh century BCE.

Homer's and Hesiod's mentions are, of course, examples of the earliest uses of this institution in the written sources. The works of other ancient Greek writers also quite frequently contain examples of settling disputes between the parties in this way. They can be found in the works of such Greek historians as Herodotus, Thucydides and Xenophon, ${ }^{3}$

${ }^{1}$ Hdt. 2.147 (about Egypt); Roebuck 2001, 6-7, 46-47, 300-302.

2 Gruen 1984, I: 96: "The Greek were litigious people. Personal and private disputes had their counterparts in quarrels at interstate level"; Roebuck 2001, 51-96. However, Strabo warned against trusting information from Homeric epics, which may be unreliable: Strabo 8.1.1.14. Interestingly, also Greek poetry from the sixth and fifth centuries contains information about mediation, adjudication and arbitration in disputes between people as well as gods, cf. Roebuck 2001, 97-106; Magnetto 2015, 65.

3 Hdt. 1.74, 96-100; 5.29, 95; 6.42, 108; Thuc. 1.28, 78, 85, 140, 144; 3. 44; 4.118; 5.31, 41, 79; Xenoph. Hell. 2.4.38; cf. Paus. 4.5.2. See Roebuck 2001, 148-161, 170-172; Magnetto 2016. 
but also Greek philosophers - Plato, Aristotle, Theophrastus ${ }^{4}$ - and orators, mainly Athenian ones, such as Demosthenes, Isocrates, Lysias, Andocides, Aeschines, etc. ${ }^{5}$ as well as great Athenian tragedians - Aeschylus and Euripides ${ }^{6}$ - and the comic playwright Aristophanes. ${ }^{7}$ Their works include numerous examples of arbitration in private, public and international matters, and describe the way it was conducted. Since many of them were Athenians, or connected with Athens in one way or another, the procedures, examples and methods of solving disputes between private individuals and communities in this city in the fifth-fourth centuries BCE are very well known to us. As a result, the majority of our knowledge about arbitration in the Classical period is about Athens and disputes between Athens and the other Greek communities. Many examples of arbitration were also recorded by Greek writers from the Hellenistic period, from Menander, Theocritus, Callimachus and Herodas to historians such as Polybius, Diodorus of Sicily, Philo of Alexandria, Dionysius of Halicarnassus, Plutarch, Pausanias and Athenaeus. ${ }^{8}$ Without doubt, another important source for studies on arbitration in the Greek world is inscriptions, especially the numerous Athenian inscriptions from the fourth century $\mathrm{BCE}$. The contents of these records are related not only to settling international disputes, but also to conflicts in individual poleis and private ones, from the sixth century BCE (the oldest one from Chios) to the second century BCE. ${ }^{9}$ A further interesting source on arbitration in the Greek world is papyrus scrolls, which show us this institution in Egypt reigned by the Ptolemies as well as under Roman rule. ${ }^{10}$

Various terms were used in Greek to refer to arbitration - dike, dikastes, dikazain, basileus - but perhaps diaita, diaitan, and dialassontas are the most suitable words for this procedure. ${ }^{11}$ The terms changed with the evolution of arbitration, which transformed from informal dispute resolution to an institution subject to state organs, which codified the principles of its functioning. ${ }^{12}$ As a result, some scholars distinguish between less formalised mediation and arbitration, which was an institutionalised form of me-

${ }^{4}$ Plat. Protag. 337-339; Nom. 4.6.23; 759b; 759c; 766d; Arist. Ath. 55; Rhet. 1.13-14; 1.13.17-19; Nic. Eth. 5.10; Theophr. fr. 650 (Wimmer 97); Roebuck 2001, 163-180.

${ }^{5}$ Lys. Theomn. 10.6; Diogeit. 32.2-3; Isocr. Antidos. 15.27, 38; Trapezitic. 17.19; Callimach. 18.4, 9-16, 27-28; Isaeus Cleonym 1.16; Dicaeogen. 5.31-33; Euphil. 12.9.11-12; Aesch. Timarch, 1.63-64; Demosth. Olimpiod. 48.2; 48.40; Macartat. 43.31; Apatur. 33.14-34; Phorm. 34.18-21; Stephen. 1.45.8; 45.17; 45.57-60; Timoth. 49.19-21; 49.55; Callip. 52.30-31; Dionysodor. 56.15; Callicl. 55.2; Meidias 21.83-95; Conon 54.26-27; Androt. 22.25-28; Everg. 47.4-5; 47.12; Neaera 59.45; Roebuck 2001, 184-246.

${ }^{6}$ Roebuck 2001, 107-130.

${ }^{7}$ Aristophanes in particular gives many examples of solving disputes by means of mediation and arbitration in private disagreements, which gives us an interesting, although perhaps exaggerated, image of Athenian society in the Classical period: Roebuck 2001, 130-147. These examples are an excellent complement to the image of private, public and international disputes recorded by the Athenian orators from that time.

${ }^{8}$ Roebuck 2001, 247-268.

9 See Piccirilli 1973; passim (from ca. 740 to 338 BCE); Ager 1996; passim (from 338 to the 90s); Roebuck 2001, 269-299 (from the early sixth century from Chios to the second century BCE); Magnetto 2016.

${ }^{10}$ Roebuck 2001, 300-343.

${ }^{11}$ Roebuck 2001, 26-47. In Athens, arbitrators in public arbitration were called klerotos (selected from many), while in private arbitration they were known as ekkletos (selected by the sides of the dispute).

${ }^{12}$ The institution of arbitration in the Roman world also evolved in a similar way. Cf. below. 
diation. ${ }^{13}$ For others, mediation is an intermediate element leading to arbitration. However, in many cases it is very difficult to distinguish between the two forms of reaching a compromise. ${ }^{14}$

The fundamental aspect of solving disputes between antagonists through arbitration was the two parties' consent that a third party (a private individual, a state, a league of states, an institution of a state or league of states, a state official - judge or ruler - in Hellenistic times, a religious institution - the Amphictyonic Council), who was regarded as neutral in the dispute, would resolve it. The person who undertook to arbitrate had to be trusted..$^{15}$ Of course, the future arbitrator had to agree to participate in resolving a dispute. ${ }^{16}$ With the evolution of arbitration mentioned above, it started to be more and more subjected to state institutions and organs - the ruler, officials and judges, who almost became mediators ex officio. This was also the case of international arbitration, which required similar mechanisms, i.e. trust in the state, a league of states, or a religious institution (a deity which was associated as the patron of such activities), who undertook to settle a dispute or who might name a possible arbitrator. What was essential in the institution of arbitration was not only trust, but also the neutrality of the future arbitrator, good relations of both sides of the dispute with the future arbitrator, goodwill shown by the arbitrator, and his authority/reputation in the Greek world. ${ }^{17}$ Both sides also had to agree (at least preliminarily) to accept the resolution proposed by the arbitrator. ${ }^{18}$ The mediator could count on receiving a reward for settling a contentious issue (mainly in the case of private arbitration).$^{19}$ Every male citizen could try to solve a dispute through arbitration (women could be represented by legal representatives), but it seems that this form was mainly available to wealthy individuals, because the side for whom the solution might be unfavourable had to bear its cost. This type of settling arguments was also available to people who were not Greek citizens, i.e. foreigners and probably freedmen. ${ }^{20}$

${ }^{13}$ Gruen 1984, I: 111; Ager 1996, xv. On the other hand, Roebuck 2001, 13-25; 358: "The processes of mediation and arbitration often intermingled but they were conceptually distinct, as shown by the precision of terminology and the formal step of swearing an oath before moving to adjudication," but 358: "The mediation element was primary." Cf. Roebuck - de Loynes de Fumichon 2004, 11-14; Ager 2009, 26-27.

${ }_{14}$ Roebuck 2001, 13-25. Cf. Ager 2009, 30-31.

${ }^{15}$ Ager 1996, 10-11; Roebuck 2001, 354-358. Contemporary scholars try to introduce a distinction between the two categories of arbitrators: Reader 1912, 143-164; Tod 1913, 70; Ager 1996, 6-8; Magnetto 2015, 65-66; 2016: "Every procedure in the process receives its legitimacy and legal form from this agreement. After the basic agreement is reached, procedures are created to deal with a great variety of situations, which differ both in terms of context and in methods. In an attempt to classify types of arbitration, Reader and Tod proposed a distinction, which soon became canonical, between compromissory arbitration and obligatory arbitration. Compromissory arbitration originates from the free agreement of the parties, without any previous pact, and is based on an agreement (compromissum), which is the outcome of the current situation. Obligatory arbitration enforces an arbitration clause included in a previous pact. These are found in the cases of alliances, treaties about isopoliteia, and agreements about judicial cooperation (symbolon)."

${ }_{16}$ Ager 1996, 11-12; Roebuck 2001, 349-350.

${ }^{17}$ Cf. Polyb. 2.39.9-10 (on the absolute honesty of the Achaeans, who were to mediate in the Lacedaemonian-Theban conflict after the Battle of Leuctra); Ager 1996, 12-13; Roebuck 2001, 354-358.

${ }^{18}$ Occasionally, the arbitrator joined one of the dispute parties, but there are more examples of this sort from Roman times.

${ }_{19}$ Ager 1996, 7, 17, 19; Roebuck 2001, 287-297. This is even more visible in Roman arbitration: Roebuck - de Loynes de Fumichon 2004, 178-192.

${ }^{20}$ Roebuck 2001, 359. 
There could be a single arbitrator or a larger number of them (a group of states or people, an institution or persons selected by an institution or institutions).

Accepting the function of arbitrator meant adopting a specific procedure, which included an oath by the arbitrator/arbitrators and a presentation of the intentions of the dispute by the two parties before the mediator. After the appointed arbitrator/arbitrators heard the parties, they examined the subject of the dispute on the spot (autopsy). The decision was made either in the location which was the subject of contention or in the state from which the arbitrators came. The safety of the arbitrators was guaranteed by the parties of the dispute. ${ }^{21}$ Hellenistic rulers rarely settled disputes at the contentious site, but rather in the place where they ruled, while the Roman Senate, after hearing the parties, sent a commission of decemviri or an appointed arbitrator/legate (official) to the spot or asked another allied state to conduct the whole procedure.22 Dissatisfaction with the result could lead to re-investigation of the matter by sending new arbitrators and re-examining the evidence. Arbitrators not only made legal decisions, but also executed them. The decisions made by arbitrators were published and communicated to both parties, but most frequently only the positive decisions for one of the parties were placed in a prominent place, such as a temple. This was to reinforce the conviction that the party in question was, for example, the rightful owner of the contentious territory, which it obtained as a result of the decision of the arbitrator(s). The documents confirming the arbitrators' decisions also included the evidence (witness testimonies), which strengthened the status of the decisions..$^{23}$

Arbitration mainly helped to solve border disputes, disagreements between states concerning matters of prestige, debts, access to resources or places of strategic importance, international treaties, as well as religious matters (control over or access to places of cult). ${ }^{24}$

In the Hellenistic period, the rulers of great powers became arbitrators, starting from Alexander the Great, but earlier Philip II of Macedon had also been a mediator. ${ }^{25}$ The power and prestige of a Hellenistic monarch made him, in the eyes of the Greek poleis, not only perfectly suited to the role, but also the guarantor of the decisions he made. ${ }^{26} \mathrm{In}$ this period, arbitration became a frequent element of international relations. No doubt, the concepts of the koine eirene and the presence of strong political bodies (Hellenistic

${ }^{21}$ Ager 1996, 14-15; Magnetto 2015, 66.

${ }^{22}$ Cf. below.

${ }^{23}$ For instance, Rhodes' arbitration in the dispute between Priene and Samos, whose final decisions appeared on a stele at Priene, in whose favour the Rhodian arbitrators decided. The earlier decision of Lysimachus, which had favoured Samos, had appeared on Samos: Ager 1996, 15-19. Cf. Magnetto 2009, 7-17.

${ }^{24}$ Gruen 1984, I: 96-99; Ager 1996, 6-10; Magnetto 2015, 66-67; Magnetto 2016.

${ }_{25}$ Ps.-Demost. 7.7.8; 7.36; 7.41; 12.11; 12.14; Aesch. 3.83; Polyb. 9.28.7; 9.33.11-12; Strabo 8.4.6 (C 361); Liv. 38.34.8; Paus. 2.20.1; 7.11.2; Tacit. Ann. 4.43.1-3; Piccirilli 1973, 222-229; Gruen 1984, II: 98; Ager 1996, 21.

${ }^{26}$ The ruler was not necessarily personally involved in arbitration, but he could have done it through his officials, legates, etc. Cf. Tod 1913, 180; Gruen 1984, I: 98: "Hellenistic princes, of course, could play a decisive role in settling or exacerbating the rifts among Greek states - when they chose"; Ager 1996, 22. Cf. Magnetto 2015, 67. 
monarchies, ${ }^{27}$ which could become guarantors of settlements in various disputes) had a large influence on resolving conflicts amicably. It seems that in the majority of cases the role of arbitrator taken on by a ruler did not stem from some cynical political games. Assuming the role of mediator, the ruler strengthened his prestige and charisma, which emphasised his power. This was important not only to his subjects, but also to his closer and more distant neighbours. It could efficiently ensure that his influence would spread without a military or a stronger diplomatic involvement, through such "soft" activities. ${ }^{28}$

We should also not forget federation states (the koinon - the Corinthian, Boeotian, Thessalian, Achaean and Aetolian Leagues) and cultic organisations (the Delphi Amphictyonic Council) as mediators/arbitrators in disputes plaguing the Greek world. Their importance and prestige, as well as their undoubted power in comparison with the strength of a single polis, played an important role in such matters. ${ }^{29}$

The political balancing act of smaller states in the Hellenistic world required behaviour which would ensure their relatively peaceful and autonomous survival among the great political players.

Arbitration as a method of settling contentious matters also functioned in Rome at least from the fifth century BCE, when this institution appeared in the Law of the Twelve Tables. ${ }^{30}$ It seems, however, that in a society such as the Roman one (clannish and with an extensive client system, where the family patriarch was also the patron of many clients connected to his family ${ }^{31}$ ), such an institution may have existed even earlier. It is difficult to imagine that the head of the family would not be the first person - due to his authority - to whom clients would turn as an arbitrator in conflicts. On the other hand, there is another aspect, i.e. disagreements between members of different clans, which needed to be resolved somehow. In the Archaic period, at the time when advanced state institutions did not exist yet, a mediator/arbitrator could be someone who was trusted by and had prestige with both sides of the conflict. We can assume as highly likely that after the state organisation was created, this person might have been the ruler.

However, the sources do not allow us to formulate bold hypotheses. Our sources, which come mainly from much later times (six hundred years and more) contain almost no data on the epoch of kings or the Early Republic. ${ }^{32}$ On the other hand, we cannot completely reject the material from the second-first century BCE to the second century $\mathrm{CE}$ as not deserving of credence. The evolution of some institutions, phenomena and offices took place in Rome, and the sources, even the later ones, show us their state in the period they described. Furthermore, writers from the Late Republic or the Early Empire based their works on much older written records and oral tradition, which are unavailable to us.

${ }_{27}$ Gruen 1984, I: 97-98; Ager 1996, 23; 2009, 16. Koine eirene: Eckstein 2008, 14, note 37.

28 Ager 1996, 22. Cf. below.

29 Ager 1996: 23-26; also examples of resolving disputes by such states and organisations. When Rome became the main player in the Greek world in the second century, it would also use the involvement of states as arbitrators, but they would be its allies! Cf. below.

30 Żołnierczuk 1978, 20-22; Roebuck - de Loynes de Fumichon 2004, 18, 29.

${ }^{31}$ Cf. Smith 2006, 168-175. Written sources on the early history of Rome and their reliability: Cornell 1995, 36-41, 57-79, 104-105; Ziółkowski 2004, 30-43; Forsythe 2005, 59-93.

32 Dion. Halic. 2.76.3 (Numa); 4.25-26 (Servius Tullius); 5.32.2; Plut. Public. 18; Mor. 250b; Zonar. 7.12 (Lars Porsenna); De Ruggiero 1898, 59, 109-110; Gruen 1984, I: 99-100, who question the reliability of these accounts. 
The institution of arbitration in Rome, and probably in Italy, functioned and developed over a long historical period. Various internal and external factors were important for the development of law (including the institution of arbitration) and its codification in the fifth century. The Greek influence, which can be observed in the evolution of Roman law, should be given special consideration. ${ }^{33}$

Terms related to the institution of arbitration and their evolution lead us to the conclusion that private and amicable mediation transformed into institutionalised arbitration, under the charge of the state. This did not mean, of course, that there was no private mediation without the state's involvement, mainly in smaller matters. The terms arbitratus, arbitrium, arbiter (as well as arbiter elegantiae in Petronius) can be traced back to the word ad+baeto(bito)+ter, which (adbito, baeto, arbitor - witness) is used, for example, by Plautus in his works. ${ }^{34}$ However, like in Greek terminology related to arbitration, there were other terms, such as iudex, centumviri, recuperatores (mediators appointed by an official), which signified not only a mediator/arbitrator, but also a judge or official, thus confirming the evolution of arbitration towards a more institutionalised form under the state's control. ${ }^{35}$ Another term which meant arbitration was compromissum, which originated from conpromittere. It appeared for the first time in the text of the senatus consultum de Bacchanalibus from 186 BCE. ${ }^{36}$

The oldest type of arbitration known from ancient Roman sources was referred to as bonus vir by Plautus, Terentius and Cato. This was a sort of mediation in which a private individual (bonus vir) was chosen by the two sides of the conflict. He had to be trusted by both parties. The bonus vir type of mediation settled matters about border disputes and other conflicts between estate owners, as well as family matters, trade disagreements, etc. ${ }^{37}$

Another kind of mediation, which was strictly controlled by state institutions, was arbitration conducted by a mediator (or mediators), referred to as iudex and selected from a special list (album). ${ }^{38}$

The third type of arbitration in Roman law was the one referred to as ex compromisso, which appeared in the second century BCE. The first mentions about it come, as we have

${ }^{33}$ Roebuck - de Loynes de Fumichon 2004, 22-24, 28-30.

${ }^{34}$ Such an evolution is described by historians of Roman law: Kaser 1996, 29-30. Arbitration/ mediation in Plautus' works: Plaut. Amphitr. 2.7-8; 16; 372; Casin. 966; Curcul. 701-704, 719-722; Mostell. 1101; Trinumm. 1161; Trucul. 629; 839-840; Terenc., Heautontimoroum. 498-501; Cato, Agric. $144.2-3 ; 145.1 ; 145.3 ; 148.1 ; 149.1-2$. According to Festus s.v. an "arbitrator": dicitur iudex, quod totius rei habeat arbitrium et facultatem. Even Jupiter was sometimes referred to as an arbitrator: CIL V 4296: fatorum arbiter: Roebuck - de Loynes de Fumichon 2004, 15-19. Cf. Żołnierczuk 1978, 25, who believed that the term arbiter originated from "ar" - an old form of the prefix "ad" - and the verb "bitere," which meant "to go." The whole word was to mean "a person who was supposed to go to a place."

${ }^{35}$ Roebuck - de Loynes de Fumichon 2004, 15. An in-depth analysis of the difference between the terms iudex and arbiter and their jurisdiction in pre-classical Roman law was carried out by Magdelain 2015, 591-652. Also see above.

${ }^{36}$ FIRA $\mathrm{I}^{2}$ 30: Neve post hac inter sed coniourase neve comvovise neve conspondise neve conpromesise velet, neve quisquam fidem inter sed dedise velet; Roebuck - de Loynes de Fumichon 2004, 19-20.

${ }^{37}$ Plaut. Trucul. 629; 839-840; Curcul. 683-686; 701-704; 719-722; Terenc. Heautontimoroum. 498-501; Cato, Agric. 2.144.2-3; 145.3; 148.1; Roebuck - de Loynes de Fumichon 2004, 46-66, who also noted this procedure in other sources, mainly legal ones.

${ }^{38}$ FIRA I $\mathrm{I}^{2}$ 3; Gell. 14.2.1-8; 11; 13-16; 20.1.7; Gai. Inst. 3.189; 4.6; 11; 13; 15; 16; 17a; Val. Max. 1.8.2; Probus 4.10; Roebuck - de Loynes de Fumichon 2004, 67-93. 
seen, from the senatus consultum de Bacchanalibus of 186 BCE. In the case of this arbitration, we are dealing with something in between the two procedures mentioned above. On the one hand, the two sides of the disagreement named a private individual as their arbitrator (in writing), while on the other hand, the state, through an official (praetor), approved their choice. This kind of arbitration ensured that private parties could settle a dispute by agreeing on a mediator in financial, trade, property, family matters etc., but the state kept an eye on the resolution (by knowing about the dispute but also controlling it to some extent). The role of the official was restricted to the minimum, but he could also appoint an arbitrator officially, if the parties could not agree on one person. ${ }^{39}$

The idea of arbitration in Rome resembled the principles of mediation followed in Greek states, which led to many similarities with regard to procedures. The choice of arbitrators, the stages of mediation and the matters which were arbitrated were similar to the ones in the Hellenic world. ${ }^{40}$

Some contemporary historians suggest, however, that the Roman Republic was not familiar with arbitration in international conflicts until it established contacts with Hellenistic states in the third/second century BCE. They try to support this thesis by citing examples from the sources which in their opinion cannot be entirely credible, because they were under heavy Greek influence or even written by authors of Greek origin. According to them, examples of Roman arbitration/mediation/adjudication in relations with other countries were merely cases of transferring Greek norms onto the Roman soil. ${ }^{41}$ However, the problem seems much more complicated. First, it is difficult to believe that prior to the period of great expansion the Romans had resolved their disputes with Italy's neighbours only by military means, especially since the proper models of resolving internal conflicts had existed in the Republic. ${ }^{42}$ Second, there were structures of confederated states functioning in Italy, which had been established not only by way of subjugating some states by the others, but also through conciliatory skills. Such structures included the Latin League, where Rome belonged as a member, not the hegemon. ${ }^{43}$

We should also remember that Rome's and Italy's contacts with the Greek world had started much earlier than the third/second century BCE - the Greek poleis in Italy and Sicily appeared even in the eighth century BCE, and these territories' relations with the Greek world were even older. ${ }^{44}$ Meanwhile, the examples of arbitration procedures between Rome and the political organisms in Italy to which the historians refer are presented in such a way as if the Romans did not know or understand them. Alternatively, they are presented as those who only cynically used this institution for their own purposes,

${ }^{39}$ FIRA III 164; Cic. Rosc. 4.10-11; Digest. 4.8.11.1; 13.1; 8.32.2; 8.32.18-20; 8.34.1; 8.47.1; 8.48; 8.49; 5.1.77; 15.1.3.9; Tacit. Ann. 1.24; Suet. Oth. 4.2; Żołnierczuk 1978, 16-19; Roebuck - de Loynes de Fumichon 2004, 94-113; Jurewicz 2011, 355.

${ }^{40}$ Roebuck - de Loynes de Fumichon 2004, 114-192. S. Ager $(2009,15-16)$ emphasises the cultural differences between the Romans and the Greeks in pursuing their diplomatic policy. A lack of understanding of the methods may have undoubtedly led to cynical abuse of the differences between the parties. However, we should also remember the similarities and mutual influences of the two civilisations, which are confirmed, for example, by arbitration procedures.

${ }^{41}$ Gruen 1984, I: 99-100.

${ }^{42}$ Cf. above.

${ }^{43}$ Ziółkowski 2004, 122-123. Cf. Bourdin 2012, 278-298.

${ }^{44}$ Roebuck - de Loynes de Fumichon 2004, 18, 29; Kuryłowicz 2013, 17-18. 
for instance, capturing the territories of those who turned to them for help in resolving a border dispute. ${ }^{45}$ Another example quoted by contemporary scholars is the mediation proposed by Pyrrhus in Rome's conflict with Tarentum in 281/280 BCE. However, we can hardly call it arbitration when one of the parties and the proposed mediator/arbitrator acted in concert. The arbitrator's impartiality was, after all, the fundamental principle of arbitration! Meanwhile, Pyrrhus arrived in Italy on Tarentum's request and cooperated with its citizens. ${ }^{46}$ Another fundamental principle of arbitration - private, public and international alike - was the acceptance of the arbitrator by the conflicted parties. ${ }^{47}$ Rome, however, did not accept Tarentum as the mediator in their struggle against the Samnites during the Second Samnite War (327-304 BCE). They also did not agree to the arbitration/mediation/adjudication of Ptolemy II between them and Carthage. They can hardly be blamed for that! ${ }^{48}$ Other states, such as Carthage and the Mamertines from Messana, also did not agree to Rome's arbitration on the eve of the First Punic War. ${ }^{49}$

It is also worth noting a few other elements which will help us understand Roman activity in the Greek world. First, the Romans did not become involved in Greek matters in order to settle disputes between the Greeks. ${ }^{50}$ Rome had its own goals in the Balkans and its own methods of achieving them, which had been established during the conquest of Italy and during the First Punic War. The Roman Republic was a state whose policies were expansive, first in Italy and later elsewhere. Even if the Roman imperial doctrine was developed much later, this does not mean that, without defining it, the Romans could not embark on their expansion. ${ }^{51}$ The fact that they did so is confirmed by successive conflicts provoked or used in order to get Rome involved. The arrival of Roman legions in the Balkans during the Illyrian Wars was not altogether coincidental. Rome ended the First Punic War (264-241 BCE), which not only gave it victory, but also turned it into a state with a mighty navy, which became an important instrument of Roman ex-

45 De Ruggiero 1898, 109-110; Gruen 1984, I: 100. The Republic took advantage of the request of Ardea and Arythia, which were involved in a border conflict in 446 BCE. Instead of arbitrating, Rome annexed the territory over which the two cities were arguing, which supposedly showed the Romans' lack of knowledge of the procedures or simply cynically taking advantage of them; cf. Livy 3.71; 4.1.4; 7.4-6; 11.2-7; Dion. Halic. 11.52; Bourdin 2005, 585-631. We should also remember that the Celtic invasion of Rome under Brennos in 390 BCE (386) was reportedly caused by the Roman legates, who had been supposed to arbitrate in a dispute between Etruscan Caere and a group of Celtic invaders, and joined their allies in Caere in their fight against the Celts. The Celtic general demanded compensation from the Romans, but they refused, which led to the invasion of Rome: Polyb. 2.18; Diod. Sic. 14.114; 117.7; Livy 5.35-50; Silius Ital. Punica 1.525; 4.150; 6.555; Plut. Camill. 22; App. Celt. 2-10; Justin 20.5; Dion 7, fr. 25.

${ }^{46}$ Livy 9.14.1; Dion. Halic. 19.9.2-4; Plut. Pyrrh. 16.3-4; Zonar. 8.3-4; Gruen 1984, I: 100; Ager 1996, 28, 94-96; Magnetto 2015, 68-69.

47 Cf. above.

${ }^{48}$ Livy 7.29-31; 8.23.8; 9.1.7; Gruen 1984, I: 100; Ager 1996, 53-54; 2009, 35-36; Burton 2011, 122-123 (the character of Rome's relations with the Samnites prior to the outbreak of the conflict). The Republic did not accept the arbitration of Tarentum, because the rites they had performed showed that the gods allowed the Romans to conduct military activities, which meant that the war was just (bellum iustum): Polyb. 1.10.1-2; Zonar. 8.8.6; Burton 2011, 128-129.

49 App. Sic. 1; Cass. Dio. fr. 43.5-6; Zonar. 8.8-9; Holleaux 1935, 65; Gruen 1984, I: 100-101; Ager 1996, 109-110; 2009, 27-29; Grabowski 2005, 85.

50 Gruen 1984, I: 99-101; Ager 1996, 26-30. Cf. Burton 2011, 201-202.

51 E. Gruen (1984, I: 277-279) is convinced that there was no coherent concept of imperial policy in the Republican period. 
pansion. ${ }^{52}$ The navy and the first conquests outside of Italy, i.e. Sicily (241), Sardinia and Corsica (238), meant that the Roman geopolitical horizon stretched beyond terra Italia, which had been the Republic's first sphere of influence and would always remain so. ${ }^{53}$ The war in Illyria was caused by the doings of the Illyrian pirates of Queen Teuta, who destabilised the situation in Greece, which the Romans cared little about. What did matter to them, however, was the fact that their allies had been attacked and threatened. The defence of attacked and exposed allies was undoubtedly a catalyst of Roman expansion (not only in propaganda terms), which was used as a way to become involved in every conflict possible in which Roman socii or amici were in genuine or imagined danger. ${ }^{54}$ No doubt, the lack of any other conflict at that time pushed the Romans to raid the Balkans, because a situation where the Republic was not at war for a prolonged period of time was not normal. The almost permanent state of war was part of the Roman mentality. The defence of the allies spurred the Republic to clash with anyone who was perceived as any sort of threat to Rome. ${ }^{55}$ Of course, the Romans became fully aware of their own power after the victory at Carthage. What all the conflicts brought - i.e. pillage, slaves, glory for the Roman generals, and the increasing sense that Rome was a guarantor of the existence of new allies - not only gave them satisfaction, but also led to new conflict situations. A new ally had its own disputes and quarrels with its neighbours, in which Rome could become involved, and consequently not only expand the number of allies, but also gain new territories, pillage, etc. ${ }^{56}$ One more thing needs to be noted in this context, which undoubtedly meant that the Romans did not feel guilty of waging war; namely the conviction that in almost all their wars they were supported by the gods - bellum iustum. All they had to do was perform a series of rituals which would help to "convince" the deities that they were in the right, and the gods would justify almost any act of aggression. ${ }^{57}$

It also seems that later contacts with the Greeks from across the Adriatic Sea were heavily influenced by the war against the king of Epirus, Pyrrhus (280-275 BCE). The Romans referred back to the events of this conflict many times when they undertook activities which impacted the Hellenistic world. The fear of the threat across the Adriatic was perhaps not as strong as the metus Gallicus or the metus Punicus, but it was

${ }^{52}$ Lazenby 2015, 43-45, 322.

${ }^{53}$ The concept of terra Italia: Ziółkowski 2004, 184-186.

${ }^{54}$ The Illyrian Wars and their significance: Holleaux 1935, 105-106, 129, 130-139; Gruen 1984, II: 359373; Eckstein 2008, 29-76; Errington 2010, 114-115, 217-219; Burton 2011, 138-142.

${ }_{55}$ Polyb. 1.37. The factors which determined Roman expansionism: Rich 2002, 44-68; Ziółkowski 2004, 164-174; Camia 2009, 167-171; Piegdoń 2014b, 87-97.

${ }^{56}$ Burton 2011, 88: "Closely related to the previous method of establishing amicitia is Rome's use of high-level diplomacy to establish contacts and solicit potential helpers in current or future zones of conflict. When warfare took the legions far from Rome, Roman generals frequently sought international amici near or within theaters of war in order to secure vital resources and infrastructure for their armies. At other times, existing amici sought third-party arbitration by the Romans in their conflicts with other states, and Rome, if such mediation was successful, extended its circle of amici to include the mediating states as well." (sic!)

57 The moment when the Romans realised their power: Ziółkowski 2004, 181-188. Bellum iustum (bellum pium): Harris 1992, 166-175; Cornell 1989, 384; Ziółkowski 2004, 166-170; Ager 2009; Yakobson 2009, 61, 63-64; Popławski 2011, 21-22. Cf. Magnetto 2015, 73-74; Masri 2016, 325-347. 
crucial in order to convince the Roman people to engage in military activities, mainly against Macedonia. ${ }^{58}$

During their earlier conquests, the Romans had developed an entire repertoire of diplomatic solutions which enabled them to build ties with other states, which then became their partners, allies, etc. It started with the foedera, used mainly in Italy, which required that Roman allies could only have diplomatic relations with Rome, while it could have relations with anyone. The attempts at arbitration by the other external political organisms mentioned above violated this fundamental principle of Roman foedus. ${ }^{59}$ We should also remember that the Romans had established various diplomatic relations with Greek states (Rhodes, the Ptolemies, Apollonia) before they started their expansion in the Greek world. ${ }^{60}$ The experiences related to the conquest of Italy, the First Punic War, and relations with other states outside of Italy enabled them to develop some "diplomatic" solutions which were hidden in the terms amicitia, clientela, deditio (deditio in fidem, in potestatem, in dicionem), fides, foedera, patrocinium, etc., and to use them also in the Hellenistic world. Incidentally, some of these terms originated from internal relations within the Roman society. ${ }^{61}$ The Romans transferred these relations to their relationships with other states. It soon turned out that they were very efficient tools of Roman diplomacy. ${ }^{62}$ It cannot be ruled out that arbitration/mediation/adjudication, in the broadest terms, was a similar case. By using it in relations with the states with which it established contacts, the Republic did, of course, pursue its own goals, but this does not mean that it did not adapt its instrumaenta imperii to the situation where they were implemented. Foedera were commonly used in relations with political bodies in Italy, while amicitia was implemented in relations with states from outside of Italy, but the Romans were flexible, and this principle was not always strictly followed. They tried to use their instruments in relations with other states they came into contact with in such a way as not to impose their solutions on them too forcefully, as long as it suited their needs. ${ }^{63}$

The Republic started the third century BCE with its expansion on Greek territory, where mediation, arbitration and all sorts of adjudication were commonly used. Over time, Rome also started to adopt these solutions more often in its relations with the Greek states. As we have mentioned above, the procedures of arbitration were not completely foreign to the Romans. Using them was not a big problem for Rome, especially since it

${ }^{58}$ Livy 31.3. Fear (metus) as a motivating factor of Roman expansion: Bellen 1985. The methods used by the Roman aristocracy to convince the populus to accept their policies (the outbreak of the Second Macedonian War): Flaig 2013, 69-151, 182-233.

59 The character of Roman alliances in Italy: Livy 34.57.7-9; Badian 1958, 23-28, 141-153; Toynbee 1965, I: 258-266; Harris 1971, 98-113; Sherwin-White 1973, 119-134; Oakley 2002, 12; Burton 2011, $28-75$.

${ }^{60}$ Holleaux 1935, 5-22, 46-53; Gruen 1984, I: 13-95.

${ }_{61}$ There is a large amount of literature about Rome's relations with states from outside of Italy, e.g.: Matthaei 1907, 182-204; Badian 1958, 55-115; Gruen 1984; Grabowski 2005, 59-310; Eckstein 2008; Burton 2011; 2015, 225-237; Snowdon 2015, 209-224. Cf. Jehne - Pina Polo 2015; J.-L. Ferrary (1988, 48, 58-69; 1995, 430-432), for instance, observed similarities between Greek solutions related to arbitration and the Roman formula of arbitrium litis estimandae in the civil law. Cf. Magnetto 2015, 72-73.

62 Gruen 1984, I: 158-202; Grabowski 2005, 36-45.

${ }^{63}$ As long as the Romans feared the intervention of a strong state (Macedonia, the Seleucid Empire), they adapted to the situation in the place where they were playing their political game. As soon as the political bodies which could have challenged them disappeared or lost their significance, they were able to introduce solutions which would subjugate relatively sovereign allies more completely. Cf. Cursi 2014, 186-195. 
could bring tangible benefits. ${ }^{64}$ The Romans turned out to be rather quick learners, and despite some initial ambiguous behaviour when Roman generals participated in settling disputes between Greek states, gradually they commonly adopted this tool in their external policies as well. ${ }^{65}$

It seems important for the entire problem to also note the way the Romans saw the matter of ownership. In Roman property law, there was a clear distinction between ownership of a thing (dominium or proprietas), or property right, and the actual possession of a thing (possessio). The Romans believed that the rightful owner of a thing did not always possess it. One could possess a thing without being its owner. This was not necessarily the result of a crime. The result of distinguishing between dominium/ proprietas and possessio was that they were assigned different instruments of legal protection. The protection of possession (possessio) was faster and easier to execute than the protection of ownership (dominium/proprietas). This is why even the rightful owner frequently preferred to use the protection of possession. Although the distinction between possession and dominium was an internal institution of Roman civil law ${ }^{66}$ and was used in relations between Roman citizens, it also became convenient in the Republic's policies related to political bodies outside of the urbs. It enabled the Romans to treat the question of their allies' ownership quite freely when they undertook to arbitrate.

In the late 220s, the position of Seleucid Egypt in the eastern part of the Mediterranean was much weaker as a result of the dynasty's internal problems. In Macedonia and the Seleucid Empire, energetic young rulers - Philip V (221-179) and Antiochus III (223-169) - ascended to the thrones. The situation changed drastically, to the Egyptian kings' disadvantage. Apart from the rivalling kings of the great Hellenistic monarchies, smaller states, such as Pergamon and Rhodes, started to play a more important role in Asia Minor, as did Rome, which came to the area at the time of the Second Macedonian War. ${ }^{67}$ All these states tried to have as big a share in the pie as possible. After the first war against Rome in 205 (the peace of Phoenice), King Philip V of Macedon became involved, like his ancestors before him (from Antigonus I Monophthalmus to Antigonus III Doson), in Asian affairs, trying to gain as much as possible from Egypt's weakness, mainly in Asia Minor. ${ }^{68}$ Also active on this territory was Antiochus III who, having returned from his expedition to the East (212-205), pursued his plan of rebuilding the Seleucid Empire within the borders it had had under Seleucus I Nicator. His general and

${ }^{64}$ For compromissum see above.

65 Polyb. 16.27; 34; 18.6; Diod. Sic. 28.6; 11; Livy 31.18; 32.10; App. Mac. 4.

66 The evolution of the concept of ownership in the Roman law: Gaius 2.40: Quo iure etami populus Romanus olim utebatur: aut enim ex iure Quiritium unusquisque dominus erat, aut non intellegebatur dominus. Sed postea divisionem accepit dominium, ut alius possit esse ex iure Quiritium dominus, alius in bonis habere; Digest. 41.2.1.3; 43.17.1.2: ...quod separata esse debet possessio a proprietate: fieri etenim potest, ut alter possessor sit, dominus non sit, alter dominus quidem sit, possessor vero non sit: fieri potest, ut et possessor idem et dominus sit (Ulpian); Kaser 1996, 122-124; György 1970, 124, 145; Du Plessis 2015, 175-176.

${ }^{67}$ Will 1966, II: 10-85; Gruen 1984, II: 532-550; Shipley 1987, 190-199; Ma 1999, 26-105; Errington 2010, 208-211, 214-215, 233-237.

68 Will 1966, II: 98-100; Gruen 1984, II: 532-538; Shipley 1987, 192-194; Reger 1999, 86-89; Errington 2010, 237-243. 
governor at Sardes, Zeuxis, was to play a special role in these plans. ${ }^{69}$ Smaller states, such as Pergamon and Rhodes, did not want to allow the Antigonids and Seleucids, cooperating on the basis of a treaty, to become stronger. The cooperation of the two rulers exposed smaller players to the danger of submission to stronger monarchs and losing their independence. Pergamon in particular, which was ruled by the Attalids, may have feared such a turn of events due to its close relations with the Seleucids, as well as its participation in the First Macedonian War on the side of the Roman Republic..$^{70}$ It should be stressed that both these states could afford to take such a position precisely due to their close relations with Rome, which was becoming increasingly involved in the area. Ptolemaic Egypt could also count, more or less hopefully, on the Republic's intervention, as Rome also maintained cordial relations (began in 272) with this state. The Republic did not want to allow the Ptolemaic monarchy to be very much weakened in favour of mighty Antiochus III and Philip V of Macedon, ${ }^{71}$ with whom it had a bone to pick for his participation in the pact with Carthage (215). It was only the ongoing Second Punic War (218-201) that prevented Rome from getting involved in the Asian matters. Philip V became very active not only on the Asian coast, but also on the Aegean Islands, trying to eliminate not only the influence of the weakening Egyptian navy, but also the increasingly more active Rhodians, who de facto took over the Ptolemies' role as guarantors of the safety of sea routes in the region. ${ }^{72}$ The pressure exerted by the Macedonian king was not limited to sabotaging the activities of the Rhodian navy with the help of hired pirate fleets. The Antigonid also subjugated some of the Cyclades (Paros, Kythnos, Andros, and perhaps Samos), which gave him not only advantageous access to the mainland but also the opportunity to control sea routes for transporting provisions for his own army in Asia Minor. ${ }^{73}$ The participation in liberating the islands of the Pergamenian and Rhodian fleets exposed Egypt's weakness; it could no longer resolutely respond either to Philip's invasion or to the ever stronger role of the Roman allies, Rhodes and Pergamon. ${ }^{74}$

The outbreak of the Second Macedonian War in 200 forced Macedonia to decrease its involvement in the East. Philip V's defeat in the Battle of Cynoscephalae in 197 and the subsequent peace treaty allowed the Romans to continue their activities in the eastern part of the Mediterranean Sea. Maintaining close relations with Pergamon and Rhodes, and skilfully using the slogan of "the freedom of Greek poleis" (which had appeared in the times of Alexander the Great, but was especially popular in his successors' times) allowed the Romans to interfere in Greek affairs in a more or less direct way. Rome's main goal was to weaken and then eliminate the influence of Antiochus III, who (after defeating Philip V) was perceived as a threat to the Republic, which did not tolerate genuine or

${ }^{69}$ I.Priene 59, ll. 2-8; 82, ll. 15-19; Will 1966, II: 96-102; Gruen 1984, II: 538-550; Shipley 1987, 192-194; Ma 1999, 53-105; Reger 1999, 86-89; Carusi 2003, 171-172; Errington 2010, 204-216.

70 Will 1966, II: 110-111; Gruen 1984, II: 538-550; Wiemer 2002, 177-288.

71 The alliance between the Ptolemies and the Republic: Grabowski 2005.

72 Justin 30.4; Magie 1950, I: 11-14; Will 1966, II: 89-90, 104-109; Shipley 1987, 194: “Philip's expedition only served to strengthen Rhodes and Pergamon. Samos was nominally Egyptian again, but Ptolemaic rule was only a name. Alexandria could not pursue an active policy in the eastern Aegean, and the Rhodians knew it"; Wiemer 2002, 97-142; 2011, 135. Cf. Gabrielsen 1997.

73 Polyb. 15.23 .4 (the effects of Philip V's activities e.g. on Kios and Thasos); Will 1966, II: 106-109; Gruen 1984, II: 532-538; Shipley 1987, 193; Hammond 1999, 312-313; Errington 2010, 237-243.

74 Berthold 1984, 102-124; Ager 1991, 10-41; Wiemer 2002, 217-234. 
suspected rivals. This worsened Rome's relations with the Seleucid Empire, whose ruler had no intention of giving up his own political plans. The relations were also influenced by the attitudes of the Republic's allies, Pergamon and Rhodes, which did not fear distant Rome but anxiously watched Antiochus III's activities in Anatolia, informing their Roman political partner about the king's moves and complaining about the more or less genuine threat posed by the Seleucid in legations which often reached the Senate. The lack of Rome's direct presence in the region, apart from few diplomatic interventions related to the Republic's impending conflict with Antiochus III, did not mean that Rome was not concerned about the situation after Philip V's retreat in $196 .{ }^{75}$

The Roman allies, the Attalids and Rhodes, continued to increase their role. The role of the latter especially grew in this area. Rhodes started to be perceived as a particularly important, prestigious ally in numerous and always ongoing disputes between Greek poleis. Magnesia and Miletus signed an agreement under the auspices of the Rhodians. ${ }^{76}$ It was also the Rhodian arbitrators who resolved the conflict between Priene and Samos (between 197/196 and 190 or after 188) which had been going on from times immemorial (the almost mythical Lelantine War in the eighth/seventh century). ${ }^{77}$ This arbitration gave a large part of the contentious territory to Priene, which subsequently placed information about this positive decision in a temple of Athena Polias. ${ }^{78}$

The Roman victory at Magnesia (in December 190 or January 189) had a large influence on the situation in the eastern part of the Mediterranean. The fate of the territories in Asia Minor and on the islands was to be decided by a special Senate committee

75 Rome's relations with Rhodes go back to the late fourth century BCE, when the two states established diplomatic relations: Polyb. 30.5.6-8; Holleaux 1935, 30-46; Berthold 1984, 147-166, 233-235; Gruen 1984, I: 68, note 74; II: 531-532. The Republic's relations with the Attalid Kingdom go back to the times of the First Macedonian War, when Pergamon was involved in Rome's war against Philip V of Macedon ca. 210 or 209 BCE: Polyb. 21.20.3; Livy 26.24.9; 29.11.2; 37.53.7; Gruen 1984, II: 530-538; Burton 2011, 86-88. Cf. Magie 1950, I: 14-18; Errington 2010, 249-258; Canali De Rossi 2016 (diplomatic relations between Rome with its allies and Antiochus III with his).

$76 S^{3} G^{3}$ 588; Ager 1996, 292-297. Cf. Reger 1999, 89-90; Wiemer 2002, 235-288; 2011, 136, even believes that "Rhodian imperialism reached its height after Antiochos III had been defeated by the Romans with the help of the Rhodian navy." The Rhodians' arbitration-related activity in the third and second century is characterised by Ager 1991, 12-29. Rhodes was not the only state to participate in such arbitration, but the Roman involvement in such enterprises is more frequently documented, cf. Livy $35.33 ; 36.31 ; 37.60 ; 38.32$; Ager 1996, 84, 86, 95-96; Magnetto 2015, 76-77.

77 Hdt. 1.147; Ps. Skylax, Periplous, 98; Hecataios (FGrH 1) F 11; Theopom. (FGrH 115) F 103; Strabo 14.1.20; Plut. Quaest. Graec. 20 = Mor. 296 A; Vitruv. Architect. 4.1.4: Haec Melite propter civium adrogantiam ab his civitatibus bello indicto communi consilio est sublata; Val. Max. 1.5: Sami Prieniensibus auxilium adversus Caras implorantibus adrogantia insticti pro classe et exercitu sibullam eis derisus gratia miserunt. Quam illi velut divinitus datum praesidium interpretati victoriae ducem habuerunt; Shipley 1987 , 29-31, 37-40; Carusi 2003, 127-136; Camia 2009, 88-93.

78 I.Priene, nos. 37-38. Cf. Shipley 1987, 197-198; Ager 1996, 91-94, 196-204; Carusi 2003, 187; Gnolli 2004, 256. Some historians date this mediation to the 180s, probably right after the Treaty of Apamea (sic!): Habicht 2003, 547-549; Bresson 2003, 186. This other dating introduces a situation in which Rhodes' arbitration took place after the conclusions of a special Senate committee of decemviri and Gn. Manlius Vulso, which established a new order in the East; cf. below. The mediators from Rhodes therefore supposedly changed the decisions of a Senate committee and a Roman governor (sic!), at least with regard to the dispute between Samos and Priene. The political reality was completely transformed in comparison to the period before the outbreak of the war against Antiochus III, because the Republic no longer had to fear any serious rivals. 
consisting of decemviri, as well as consul Gn. Manlius Vulso, successor of the Roman commander in the war against Antiochus III, L. Cornelius Scipio. The majority of Antiochus III's domains in Asia Minor was divided between two Roman allies, Pergamon and Rhodes, which showed quite fierce rivalry before the Senate in Rome, wanting to gain as much as possible, to the detriment of the other party. ${ }^{79}$ For Samos, the Roman decisions meant positive arbitration in the dispute with Priene. Vulso gave the contentious territories not to Priene, but to Samos. ${ }^{80}$ There have been suggestions (Livy) that this decision, beneficial for the island, was not a result of Rome's impartiality, but of corruption. However, we should not forget the important role Samos had played in Rome's war against the Seleucid monarch, as well as its contributions to the Republic's cause. ${ }^{81}$

Vulso's decision, undoubtedly favourable to Samos, did not resolve the seemingly never-ending dispute between Priene and Samos. If we do not count the mediation of the Roman ally, Rhodes - the precise dating of which, as we have seen, is quite debatable (before or after the Treaty of Apamea) (2) $^{82}$ the dispute returned in a completely changed geopolitical situation in Asia Minor half a century after the Senate and Consul Vulso's decision. There were no strong political bodies any more, which could in any way influence the Roman policy in the region: Macedonia had become a Roman province; the Seleucids were resisting pressure from the Parthians with increasing difficulty, and their domains had been reduced to a scrap of their former territory; Ptolemaic Egypt was more and more dependent on Roman influence; and the old Roman allies, Rhodes and Pergamon, were no longer needed by the Republic. They had either been completely marginalised politically and weakened economically, like Rhodes (after the Third Macedonian War), or Rome was preparing to take over its ally's territory, like in Pergamon's case (in 133). ${ }^{83}$ The matter of the dispute returned to the Roman Senate (ca. 135), which changed the previous decision of its legates. This time, the Roman arbitrators gave the contentious territory to Priene, taking it away from Samos and appointing a polis (unknown by name to us), which was to make sure that the border markers would be maintained. The decision was a repeat of the one made by the Rhodian arbitrators, who had given the contentious territory to Priene. ${ }^{84}$ The arbitrators' decision is all the more surprising because Samos played a positive role for the Republic at the time when Pergamon was taken over (on the basis of the testament made by the last king of the Attalid dynasty,

${ }^{79}$ Polyb. 21.18-24, 35, 41-46; Livy 37.56; Magie 1950, I: 108-109; Will 1966, II: 181-199; Shipley 1987, 197-198; Bresson 1998, 68-77; 1999, 98-118; Gnolli 2004, 256; Errington 2010, 268-279; Wiemer 2011, 135-136 (Rhodes); Canali De Rossi 2017. Cf. Burton 2011, 199-201.

${ }^{80}$ I.Priene, nos. 40-41; Ager 1996, 204-209, 270. The situation of poleis in Anatolia: Errington 2010, 280-283.

${ }^{81}$ This is suggested by L. Furius Purpureo's and L. Aemilius Paullus' speeches in the Senate: Livy 38.45; Shipley 1987, 198; Carusi 2003, 188; Heller 2006, 41. Cf. Vulso's behaviour towards the Galatians: Gruen 1984, II: 549-550.

${ }^{82}$ Cf. above.

${ }^{83}$ Generally: Will 1966, II: 240-252, 319-324, 352-356; Gruen 1984, II: 550-610; Derow 1989, 290 323; Habicht 1989, 324-387; Errington 2010, 309-317. Rhodos: Berthold 1984, 167-212; Ager 1991, 29-41; Bresson 1999, 118-120; Wiemer 2002, 289-340; 2011, 135; Dmitriev 2011, 284-312.

${ }^{84}$ I.Priene, no. 40, ll. 4-10; 41-42; Shipley 1987, 198; Ager 1996, 270-271, 451-457; Carusi 2003, 187-190; Camia 2009, 94-96. Perhaps even this decision did not end the dispute between the two poleis: Ager 1996, 500. Some historians date this arbitration to the period after 133: Magnetto 2016. 
Attalus III) and during Aristonicus' fight for the throne at the turn of the 130 s and the 120s. ${ }^{85}$ Perhaps it was this unfavourable Roman arbitration that made the Samians help the Romans to deal with Aristonicus? ${ }^{86}$

It would seem that until the Roman Republic became involved in Greek affairs in the late third and second centuries, we indeed do not know of many cases where it used arbitration in the foreign policy. It was only Rome's expansion in the Hellenistic world that led the Romans to make use of this diplomatic instrument, so common and popular among the Greeks. We should remember, however, that Rome entered these territories with its own political goals and instruments for achieving them. The Romans did not want to become the mediators of the Greek world, but it was important to them to take advantage of the situation they encountered in the region. It was not a planned-out policy of expansion which they would implement step by step. It was the Greeks, used to employing various (more or less sophisticated) political instruments, who perceived the new player in their world in this light. We can also assume that Rome did not become an arbitrator in Greek matters of its own will, but because of the role it was given by the Greek world when the Republic's power replaced the Hellenistic powerbrokers. Rome became involved in resolving disputes in the Greek world only when it had to. The Senate did not want to be an "arbitration court" for the conflicted Greek states. ${ }^{87}$

Roman arbitrators acted on the basis of the powers given to them by the Senate ( $\mathrm{se}$ natus consulta), which first familiarised itself with the heart of the matter. The resolution of the dispute was usually made by Roman officials (proconsul, governor) or special legates (decemviri) with prepared instructions, which gave them the power to resolve the matter on the spot and to execute the decision. ${ }^{88}$ The procedure was in force both in the Greek world and in Italy, which from the second century BCE was also a place of frequent mediations and arbitrations. ${ }^{89}$ However, what distinguished mediation in Italy

${ }^{85}$ Strabo 14.1.38 (646C); Flor. 1.35.4; Gnolli 2004, 257-258. On the other hand, it should be remembered that the Romans had supported Priene in a conflict between this polis and Cappadocia's new ruler, Ariarathes V: OGIS 351 = I.Priene, no. 39; Sherk 1984, no. 33 B; Polyb. 33.6.1-2; 6.6-9; Diod. Sic. 31.32. The intervention is dated to 155/154 BCE: Ager 1996, 392-394.

${ }^{86}$ Gnolli 2004, 258-262.

${ }^{87}$ Marshall 1980, 626-662; Ager 1996, 26-30; Camia 2009, 186-210.

${ }_{88}$ Marshall 1980, 626-662; Ager 1996, 26-30. For instance, the arbitration of Q. Fabius Labeo and App. Claudius Pulcher in the never-ending dispute between Gortyna and Knossos in 184: Polyb. 22.15; Livy 37.60.3-6; Ager 1996, 262-263, 297-298. Cf. Cary 1926, 196-200.

${ }^{89}$ The sources provide a great deal of information, especially about mediation and arbitration in northern Italy: FIRA 21; CIL I² 633, 725 = V $2491=I L S$ 5944a = ILLRP 476 (Cippo del Monte Venda); CIL I $\mathrm{I}^{2} 634=$ V $2492=I L S 5944=I L L R P 476$ (Cippo di Teolo); CIL I I 2501 = ILLRP 476 (Cippo di Galzigano); CIL I ${ }^{2} 636$ =V $2490=$ ILS 5945; ILS 5946 42-44 (Tabula Polcevera); Livy 32.30; 39.3; 42.7-9, 10, 21; 43.5.1-10; 45.13; Diod. Sicul. 29.14; Plut. Flamin. 1; Sherwin-White 1973, 128; Buonopane 1992, 207-233; Calderazzo 1997, 25-46. We should particularly note one of the arbitrators from northern Italy, M. Aemilius Lepidus, consul of 187 and 175, who started his career in the Hellenistic world. Despite his young age, he performed various honourable diplomatic functions in the Hellenistic world - he was a legate sent to Philip V of Macedon: Polyb. 16.27; 34.34; Livy 31.2, 18; Badian 1958, 64, 107, note 2, 109, note 4, 110, note 3; Eckstein 2008, 276-278, 290; Grabowski 2005, 96-126, but he also played an important role in the Republic's relations with the Ptolemies: Polyb. 15.25; Val. Max. 6.6.1; Iustin. 31.1.2; Badian 1958, 63, note 3, 64, 70; Braund 1984, 136; Eckstein 2008, 204-206; Grabowski 2005, 121-126. For M. Aemilius Lepidus, see Rossignani 1995, 61-75; Piegdoń 2014a, 197-208. We should also not forget Roman arbitration in the disputes between Carthage and the Numidian King Masinissa before the city was destroyed in 146: Livy 34.62; 42.23-24. 
and the western part of the Roman dominion from the Greek world was the fact that the Republic appointed other Greek states (poleis or leagues) to act as an arbitrator on its behalf. ${ }^{90}$ Deciding to become mediators or arbitrators, the Romans were not especially interested in the history of the dispute, but resolved it on the basis of the status quo, without going into the details of who had been in the right in the past. This made it easier for them to side with their allies who were a party to the dispute, even if they were in the wrong. Such an attitude protected the interests of the allied state, unless it was beneficial for Rome to violate them. ${ }^{91}$ This was another sphere in which the Roman approach was extremely pragmatic.

ABBREVIATIONS

CIL - Corpus Inscriptionum Latinarum.

FIRA - S. Riccobono et al., Fontes Iuris Romani Antejustiniani, Firenze.

ILLRP - A. Degrassi, Inscriptiones latinae liberae rei publicae, Firenze 1957-1963.

ILS - H. Dessau, Inscriptiones latinae selectee, Berlin 1892-1916.

I.Priene - F. Hiller von Gaertringen, Inschriften von Priene, Berlin 1906.

BIBLIOGRAPHY

Ager, S.L. (1991), Rhodos: The Rise and Fall of a Neutral Diplomat, Historia 40: 10-41.

Ager, S.L. (1996), Interstate Arbitrations in the Greek World, 337-90 B.C., Berkeley.

Ager, S.L. (2009), Roman Perspectives on Greek Diplomacy. The Conceptual Clash: Greek Diplomacy of Compromise and Roman iustum bellum, in: C. Eilers (ed.), Diplomats and Diplomacy in the Roman World, Leiden-Boston: 28-58.

Badian, E. (1958), Foreign Clientelae 264-70, Oxford.

Bellen, H. (1985), Metus Gallicus - Metus Punicus. Zum Furchtmotive in der römischen Republik, Wiesbaden-Stuttgart.

Berthold, R.M. (1984), Rhodes in the Hellenistic Age, Ithaca-London.

Bourdin, S. (2005), Ardée et les Rutules : réflexions sur l'émergence et le maintien des identités ethniques des populations du Latium préromain, MEFR 117 (2): 585-631.

Bourdin, S. (2012), Les peoples de l'Italie préromaine. Identités, territoires et relations inter-ethniques en Italie centrale et septentrionale (VIII ${ }^{e}-I^{e r}$ s. av. J.-C.), Rome.

Braund, D.C. (1984), Rome and the Friendly Kings: The Character of Client Kingship, New York.

${ }^{90}$ For instance, the appointment of Mylasa as the arbitrator in the dispute between Magnesia and Priene ca. 175-160: Ager 1996, 27, 321-328.

${ }^{91}$ Ager 1996, 26-30. S. Ager (2009, 30-32) proposes that we should stop using the terms "meditation" or "arbitration" to describe Rome's role in relations with the Greek world. She suggests replacing them with the term "deprecation," which is to mean "begging or entreaty, in particular to avert some evil." 
Bresson, A. (1998), Rhodes, Cnide et les Lyciens au début du II ${ }^{\mathrm{e}}$ siècle av. J.-C., RÉA 100: 65-88.

Bresson, A. (1999), Rhodes and Lycia in Hellenistic Times, in: V. Gabrielsen (ed.), Hellenistic Rhodes: Politics, Culture, and Society, Cambridge: 98-131.

Bresson, A. (2003), Les intérêys rhodiens en Carie à l'époque hellénistique, jusqu'en 167 av. J.-C., Pallas 62: 169-192.

Buonopane, A. (1992), La duplice iscrizione confinaria di Monte Venda (Padova), in: L. Gasperini (ed.), Rupes loquentes, Roma: 207-223.

Burton, P.J. (2011), Friendship and Empire: Roman Diplomacy and Imperialism in the Middle Republic (353-146 B.C.), Cambridge.

Calderazzo, L. (1997), Arbitrati romani in Cisalpina (197-89 a.C.): problemi e status quaestionis, Rivista di studi Liguri 62: 25-46.

Camia, F. (2009), Roma e le poleis. L'intervento di Roma nelle controversie territoriali tra communità greche di Grecia e d'Asia Minore nel secondo secolo a.C.: le testimonianze epigrafiche, Atene.

Canali De Rossi, F. (2016), Le relazioni diplomatiche di Roma, vol. V: Dalle pace infida alla espulsione di Antioco dalla Grecia (194-190 a.C.), Roma.

Canali De Rossi, F. (2017), Le relazioni diplomatiche di Roma, vol. VI: Dalla spedizione degli Scipioni in Asia alla pace di Apamea (190-188 a.C.), Roma.

Carusi, Ch. (2003), Isole e peree in Asia Minore. Contributi allo studio dei rapporti tra poleis insulari e territory continentali dipendenti, Pisa.

Cary, M. (1926), A Roman Arbitration in the Second Century B.C., JRS 16: 196-200.

Cornell, T. (1989), The Conquest of Italy, $C A H^{2}$ VII: 351-419.

Cornell, T. (1995), The Beginnings of Rome: Italy and Rome from the Bronze Age to the Punic Wars (c. 1000-264 BC), London-New York.

Cursi, M.F. (2014), International Relationships in the Ancient World, Fundamina 20: 186-195.

De Ruggiero, E. (1898), L'arbitrato pubblico in relazione col private presso i Romani, Roma.

Derow, P. (1989), Rome, the Fall of Macedon and the Sack of Corinth, CAH' VIII: 290-323.

Dmitriev, S. (2011), Rhodes between Rome and Perseus, in: S. Dmitriev, The Greek Slogan of Freedom and Early Roman Politics in Greece, Oxford: 284-312.

Du Plessis, P. (2015), Property, in: D. Johnson (ed.), The Cambridge Companion to the Roman Law, New York: 175-198.

Eckstein, A.M. (2008), Rome Enters the Greek East: From Anarchy to Hierarchy in the Hellenistic Mediterranean, 230-170 B.C., Oxford.

Errington, R.M. (2010), Historia świata hellenistycznego 323-30 p.n.e., transl. A. Gąsior-Niemiec, Kraków.

Ferrary, J.-L. (1988), Philhellénisme et impérialisme. Aspects idéologiques de la conquête romaine du monde hellénistique, de la seconde guerre de Macédoine à la guerre contre Mithridate, Rome.

Ferrary, J.-L. (1995), Ius fetiale et diplomatie, in: E. Frézouls, A. Jacquemin (eds.), Les relations internationales. Actes du Colloque de Strasbourg (15-17 juin 1993), Paris: 411-432.

Flaig, E. (2013), Zrytualizowana polityka rzymska. Znaki, gesty i władza w starożytnym Rzymie, Poznań.

Forsythe, G. (2005), A Critical History of Early Rome, Berkeley-Los Angeles-London.

Gabrielsen, V. (1997), The Naval Aristocracy of Hellenistic Rhodes, Aarhus.

Gnolli, T. (2004), Samo in èta ellenistica e romana: ricerche, storiche ed epigrafiche, in: E. Cavallini (ed.), Samo, storia, letteratura, scienza. Atti delle giornate di studio, Ravenna, 14-16 novembre 2002, Pisa-Roma: 249-274.

Grabowski, T. (2005), Ptolemeusze i Rzym. Przyjaźń czy zależność, Kraków.

Gruen, E. (1984), The Hellenistic World and the Coming of Rome, 2 vols., Berkeley.

György, D. (1970), Ownership in Ancient and Preclassical Roman Law, Budapest.

Habicht, C. (1989), Seleucids and Their Rivals, $C A H^{2}$ VIII: 324-387.

Habicht, C. (2003), Rhodian Amphora Stamps and Rhodian Eponyms, RÉA 105: 541-578.

Hammond, N.G.L. (1999), Starożytna Macedonia. Poczatki, instytucje, dzieje, transl. A.S. Chankowski, Warszawa. 
Harris, W.V. (1971), Rome in Etruria and Umbria, Oxford.

Harris, W.V. (1992), War and Imperialism in Republican Rome 327-70 B.C., Oxford.

Heller, A. (2006), „Les bêtises des Grecs”. Conflicts et rivalités entre cites d'Asie et de Bithynie à l'époque romaine (129 a.C.-235 p.C.), Bordeaux.

Holleaux, M. (1935), Rome, la Grèce, et les monarchies hellénistiques au III ${ }^{e}$ siècle avant J.-C. (273-205), Paris.

Jehne, M., Pina Polo, F. (eds.) (2015), Foreign clientelae in the Roman Empire: A Reconsideration, Stuttgart.

Jurewicz, A.R. (2011), Organizacja wymiaru sprawiedliwości, in: A. Jurewicz, R. Sajkowski, B. Sitek, J. Szczerbowski, A. Świętoń (eds.), Rzymskie prawo publiczne. Wybrane zagadnienia, Olsztyn: 319-394.

Kaser M. (1996), Das römische Zivilprozeßrecht, 2 Aufl., München.

Kuryłowicz, M. (2013), Prawo rzymskie. Historia, tradycja, wspótczesność, Lublin.

Lazenby, J.F. (2015), Wojna Hannibala. Historia militarna drugiej wojny punickiej, transl. T. Ładoń, Oświęcim.

Ma, J. (1999), Antiochos III and the Cities of Western Asia Minor, Oxford.

Magdelain, A. (2015), Aspects arbitraux de la justice civile archaïque à Rome, in: Ius Imperium Auctoritas. Études de droit romain, Rome: 591-652.

Magie, D. (1950), Roman Rule in the Asia minor to the End of Third Century after Christ, 2 vols., Princeton.

Magnetto, A. (2009), La querelle territoriale entre Samos et Priène. Propositions pour un débat, Topoi $16: 7-17$.

Magnetto, A. (2015), L' arbitrato dei Romani nel rapporto con la diplomazia dei Greci. Alcuni spunti di riflessione, in: B. Grass, G. Stouder, J.L. Ferrary, S. Pittia, P. Sanchez (eds.), La diplomatie romaine sous la République: réflexions sur une pratique, Besançon: 65-86.

Magnetto, A. (2016), Interstate Arbitration and Foreign Judges, in: E.M. Harris, M. Canevaro (eds.), The Oxford Handbook of Ancient Greek Law, Oxford, Online Publication Date: Jul 2016, DOI: 10.1093/oxfordhb/9780199599257.013.20.

Marshall, A.J. (1980), The Survival and Development of International Jurisdiction in the Greek World under Roman Rule, $A N R W$ II 13: 626-662.

Masri, L. (2016), Rome, Diplomacy, and the Rituals of Empire, Historia 65: 325-347.

Matthaei, L. (1907), On the Classification of the Roman Allies, CQ 1: 182-204.

Oakley, S. (2002), The Roman Conquest of Italy, in: J. Rich, G. Shipley (eds.), War and Society in the Roman World, London-New York: 9-37.

Piccirilli, L. (1973), Gli arbitrati interstatali greci, Firenze.

Piegdoń, M. (2014a), Viam feceit... ponteis... poseivei... forum aedisque poplicas heic fecei: Political Activity of M. Aemilius Lepidus in Northern Italy, in: K. Twardowska, M. Salamon, S. Sprawski, M. Stachura, S. Turlej (eds.), Within the Circle of Ancient Ideas and Virtues: Studies in Honour of Professor Maria Dzielska, Kraków: 197-208.

Piegdoń, M. (2014b), Some Remarks on War Rituals in Archaic Italy and Rome and the Beginnings of the Roman Imperialism, Electrum 21: 87-97.

Popławski, M.S. (2011), Bellum Romanum. Sakralność wojny i prawa rzymskiego, Lublin.

Raeder, A. (1912), L'arbitrage international chez les Hellènes, Kristiania.

Reger, G. (1999), The Relations between Rhodes and Caria from 246 to 167 BC, in: V. Gabrielsen, P. Bilde, T. Engberg-Pedersen, L. Hannestad, J. Zahle (eds.), Hellenistic Rhodes: Politics, Culture, and Society, Cambridge: 76-97.

Rich, J. (2002), Fear, Greed and Glory: The Causes of Roman War-making in the Middle Republic, in: J. Rich, G. Shipley (eds.), War and Society in the Roman World, London-New York: 44-68.

Roebuck, D. (2001), Ancient Greek Arbitration, Oxford.

Roebuck, D., Loynes de Fumichon, B. de (2004), Roman Arbitration, Oxford. 
Rossignani, M.P. (1995), Gli Aemili e l'Italia del Nord, in: G. Cavalieri Manasse, E. Roffia (eds.), Splendida civitas nostra. Miscellanea di studi archeologici in onore di Antonio Frova, Roma: 61-75.

Sherk, R. (1984), Rome and the Greek East to the Death of Augustus, Cambridge.

Sherwin-White, A.N. (1973), The Roman Citizenship, Oxford.

Shipley, G. (1987), A History of Samos 800-188 BC, Oxford.

Smith, J.C. (2006), The Roman Clan: The Gens from Ancient Ideology to Modern Anthropology, Cambridge.

Snowdon, M. (2015), Beyond Clientela: The Instrumentality of Amicitia in the Greek East, in: M. Jehne, F. Pina Polo (eds.), Foreign clientelae in the Roman Empire: A Reconsideration, Stuttgart: 209-224.

Tod, M.N. (1913), International Arbitration amongst the Greeks, Oxford.

Toynbee, A.J. (1965), Hannibal's Legacy: The Hannibalic War's Effects on Roman Life, 2 vols., London.

Wiemer, H.-U. (2002), Krieg, Handel und Piraterie: Untersuchungen zur Geschichte des hellenistischen Rhodos, Berlin.

Wiemer, H.-U. (2011), Early Hellenistic Rhodes: The Struggle for Independence and the Dream of Hegemony, in: A. Erskine, L. Llewellyn-Jones (eds.), Creating a Hellenistic World, Oxford: 123-146.

Will, E. (1966), Histoire politique du monde hellénistique (323-30 av. J.-C.), 2 vols., Nancy.

Yakobson, A. (2009), Public Opinion, Foreign Policy and 'Just War' in the Late Republic, in: C. Eilers (ed.), Diplomats and Diplomacy in the Roman World, Leiden-Boston.

Ziółkowski, A. (2004), Historia Rzymu, Poznań.

Żołnierczuk, M. (1978), Rzymskie sądownictwo polubowne (okres przedklasyczny i klasyczny), Lublin. 